\title{
E-Assessment on Student's Self-Concept for Physics Learning
}

\author{
Astalini *, Darmaji, Dwi Agus Kurniawan, Lika Anggraini, Rahmat Perdana \\ Universitas Jambi, Jl. Raya Jambi, KM 15, Mendalo Indah, Jambi, 36361 \\ ${ }^{1}$ dwiagus.k@unja.ac.id \\ * corresponding author
}

\begin{tabular}{|c|c|}
\hline ARTICLE INFO & ABSTRACT \\
\hline \multirow[t]{3}{*}{$\begin{array}{l}\text { Article history } \\
\text { Received July 7, } 2019 \\
\text { Revised August 11, } 2019 \\
\text { Accepted November 16, } 2019\end{array}$} & $\begin{array}{l}\text { This study aims to apply students' self-concept E-assessment to SESKA-based } \\
\text { physics. Student self-concept E-assessment in this study aims to see students } \\
\text { 'self-concept of physics and how the teacher responds to the development of stu- } \\
\text { dents' self-concept E-assessment with SESKA systems. The method implemented } \\
\text { in this research has three stages, namely: (1) Development, (2) Implementation, } \\
\& \text { (Evaluation). This research was carried out on } 450 \text { students and } 15 \text { teachers in } \\
\text { the Jambi Province of Indonesia. The results of this study indicate students' self- } \\
\text { concept of physics is classified as good } 47.1 \% \text { ( } 212 \text { students), and the teacher's } \\
\text { response is classified as positive, with } 66.7 \% \text { (10 teachers). Therefore, SESKA- } \\
\text { based E-Assessments receives a good response and needs to be developed on a } \\
\text { large scale. }\end{array}$ \\
\hline & This is an open access article under the CC-BY license. \\
\hline & (c) \\
\hline
\end{tabular}

\section{Introduction}

Education is the most important aspect for everyone in a country. Through education, it is expected that educators can prepare students' abilities to play an active role in becoming qualified human resources in the era of globalization. Therefore, every quality of education that exists in a country affects the progress of that country. The realm of education contributes to the development of the civilization of the nation's life (Karyadi et al., 2018). Assessment in education is necessary to know the level of success and efficiency of the learning process in facing the challenges of education. With an objective assessment, it will be known what to look for in a particular case.

Assessments can be carried out for a variety of reasons and intentions that give the practice a certain perspective (Fuller, 2013). Assessment from an educational perspective is one of the important things to do. The assessment has a crucial role in education (Heitink et al., 2016). Assessment in education is defined as an evaluation to find out how education works effectively for each student. Assessment in education is not only limited to assessing the cognitive level and intelligence of students but also in assessing the affective domain of students or characters. Character good objectivity that shows human quality, whether known to humans or not and goodness, is affirmed by society and religion. Today's character becomes one of the main concentrations developed in each student because the character is related to students' attitudes in controlling their behavior. The concern for knowledge in education is included in the aspects of values, attitudes, man- 
ners, and other good characters (M. N. Abdullah \& Kadhim, 2016).

Students ' character ratings are crucial, as they can find out the relatively stable individual's behaviors or attitudes. Attitude is often regarded as the personal trust of each individual that is stable and difficult to change (van Aalderen-Smeets et al., 2017). One character that can be developed for students is selfconcept. The concept of self is said to be an assumption to someone who feels comfortable with themselves and their own abilities (Lawrence \& Vimala, 2013). In relation to selfconcept, learning needs to be developed in a positive direction to form good self-confidence. Self-concept consists of two aspects, namely physical self-concept, which is reflected in its appearance, and psychological self-concept that is detailed on academic self-concept and social self-concept (Dwija, 2008). The importance of increasing positive self-concept will have a good impact on the behavior and attitudes that a person has in learning.

The self-concept character assessment, in this case, focuses on the object of physics. Because physics not only teaches about the concepts of nature and technology but also teaches character. Science or science learning, in essence, has dimensions of thinking abilities, dimensions of products, and dimensions of development of attitude or character (Pratiwi \& Fasha, 2015). Physics learning is essential for every student. Science has been introduced since basic education; science is a continuous process of learning (Narmadha \& Chamundeswari, 2013). Physics generally contains material about nature, environment, and technological development. Science education researchers have the concept of science (Topcu $\&$ Şahin-Pekmez, 2009). The self-concept character assessment of physics has a definition of the assessment of student attitudes and student behavior, which tends to be consistently carried out continuously in physics lessons at school.

Character evaluation is generally done conventionally and traditionally. Generally, the researcher conduct research related to the character of students in school using a questionnaire instrument. (Cohen et al., 2013) state that researchers must judge the correct questionnaire used for data collection, and, if so, what kind of questionnaire it will be. Commonly, the questionnaire used to evaluate students' character employs a Likert scale. (Joshi et al., 2015) mention that the Likert scale is one of the most fundamental and frequently used psychometric tools in educational and social sciences research. The Likert scale describes the level of agreement or disagreement of the research subject. This research used a paper-based questionnaire. Because this questionnaire was paper based, the research evaluating the character of students' self-concept towards physics was carried out by directly distributing the questionnaire to each student.

The evaluation of the character of selfconcept towards physics with a paper-based questionnaire has a weakness, namely the excessive disposal of paper and the effect on the quantity of waste and less effective and efficient. (Birenbaum et al., 2006) state, in general, current assessment systems tend to be aneconomical, time-consuming, not costeffective, and demotivating both for learners and teachers. That problem can be answered by technology and computers that can change the system to be computerized in the form of an Eassessment (Sahidu et al., 2017). With the development trend of the industrial revolution 4.0, the implementation of the educational process should follow the 4.0 industrial revolution. 4.0 industrial revolution-based learning has the characteristic always to use internet networks and technology. One of them is the development of E-learning. E-learning is the most recent way to carry out distance education by distributing learning materials and processes over the Internet (Ardito et al., 2006). In line with the development of E-Learning, the development of E-assessment to assess students' self-concept of physics should also be started

Therefore, by following the development of industry 4.0 in the world of education, the researchers developed E-assessment by developing a SESKA system program for concept characters self. This E-assessment of students' self-concept in physics will be more effectively and efficiently developed in character research because it can be used remotely without faceto-face research with respondents and is interactive. This SESKA System development for E-assessment on students 'self-concept character is not only beneficial for researchers but also for teachers. Besides, being educators, teachers also have the role of being evaluators.

As an evaluator, the teacher must be able to carry out assessments on learning outcomes and evaluate, as well as controlling student learning activities (Ismail, 2010). As an evaluator, the teacher can utilize the self-concept Eassessment of the physics with the SESKA sys- 
tem to find out how the character of students' self-concept towards physics, which is useful for learning effectiveness. The homepage of the SESKA system is presented in Fig. 1.

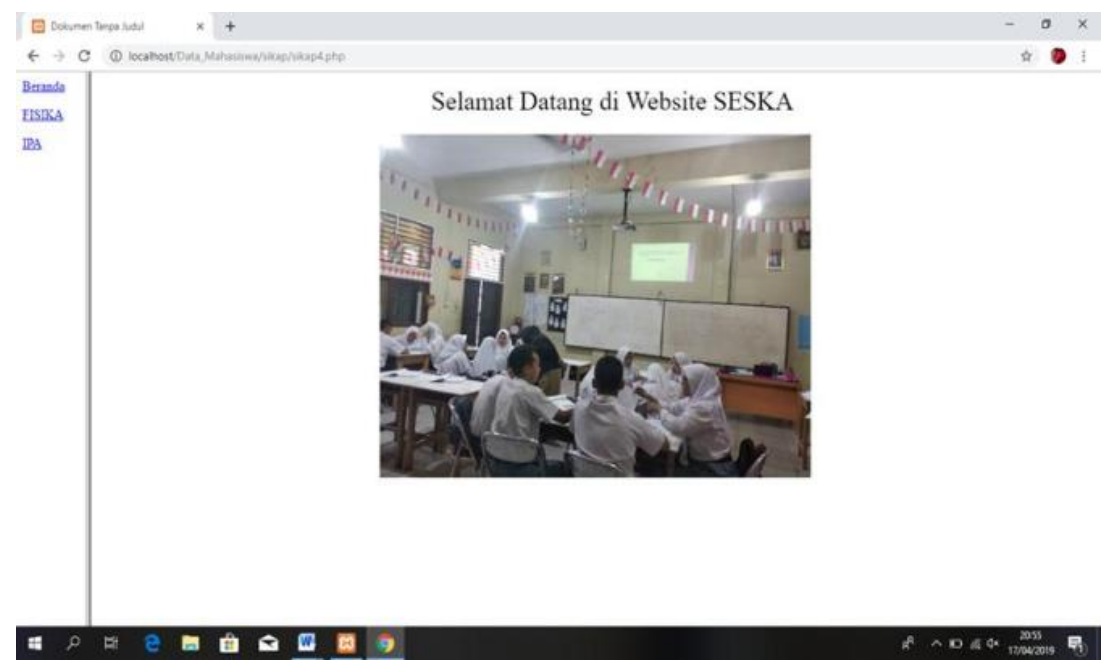

Fig. 1.SESKA Website Homepage (Welcome to the SESKA Website/Welcome On Website SESKA)

SESKA system is for E-Assessment. Therefore, education systems recognize the key role of information communication technology in transforming education to meet the needs of the

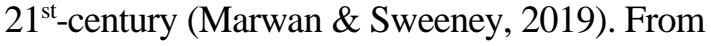
the explanation above, the focus of the research in this study is outlined in the research question below:

How does the assessment of self-concept of self towards physics use e-assessment by using a SESKA system program?

What is the teacher's response to the development of self-concept character assessment of physics using the SESKA system?

\section{Method}

This research uses three stages research method, namely: 1. Development, 2. Implementation, 3. Evaluation. In detail, the research phase is explained as follows:

In the development stage, Self-concept questionnaire E-assessment physics was developed. This stage includes limiting the measurement indicators of self-concept in physics learning. There are eight indicators that measure students' self-concept in physics, namely: (1) Self-esteem, (2) the perpetrator himself, (3) The judge himself, (4) The Physical Self, (5) The ethical self-immoral, (6) Personal self, (7) The Family Self, (8) the social self. The measurement indicators of students 'self-concept towards physics aim to prepare relevant statements related to students' self-concept in physics. Each of these indicators was compiled into statements relating to the character of students' self-concept towards physics. From these statements, the students' self-concept of physics questionnaire was developed. Students' selfconcept of physics in the questionnaire became the basis of developing an E-assessment with the SESKA system. In addition, the development and manufacture of E-assessment were based on the flowchart and storyboard of analysis of hardware (software) and software requirements analysis. The final stage was the conceptual E-assessment of character input on physics in the SESKA system. This SESKA used MySQL. The development and data collection employed open-source software. Recorded data from sensors in the MySQL database were hosted on a web-based dashboard GUI using the PHP scripting language (Thapliyal \& Kumar, 2016).

The implementation phase began with the steps to simulate and apply the student's selfconcept E-assessment on physics to the students and teachers. The initial step was an Eassessment simulation to a small group. Then a small group trial was conducted to find out how students assess the students' self-concept EAssessment. The result of that small group trial shows that the E-assessment self-concept of physics is feasible to be used. In this stage, the self-concept E-assessment was carried out to 450 high school students and 30 teachers. This stage was a large group trial. Trials were conducted along with the software development stage. This implementation involved prospective users, educators, and students (Retnawati et al., 2017). 
In the Evaluation Phase, a comprehensive evaluation of the E-assessment of the concept of self-concept towards Physics using the SESKA system was carried out. The evaluation process aims to improve its weakness, so it is appropriate to be used to connect the designers and users directly to assess the physical concept of students through the website system of SESKA. The evaluation phase is the last stage before the E-assessment is determined to be feasible for wide-scale usage with a large sample of various respondents in the area. This step intends to open chances for all stakeholders to use the students' self-concept E-assessment of physics with the SESKA system.

This research was conducted with a sample of 450 students and 15 teachers as respondents. The student samples came from 2 schools, Public High School 8, State High School 6, in Batanghari Regency, Jambi Province, Indonesia. And for teachers, they are physics teachers in Jambi Province, Indonesia. The sampling technique used was the purposive sampling technique. This sample was taken based on predetermined criteria, namely nationally accredited schools.

\section{Results and Discussions}

The results of the study were attained from data of self-concept character E-assessment via the "SESKA" program which had been filled by students and teachers as respondents. This data was input automatically on the "SESKA" database. The obtained data was in the form of quantitative data. To see the self-concept of physics in detail, it was analyzed using descriptive statistics. This statistic is used along with IBM SPSS Statistics software.

Character and computation-based evaluation of networks should be the most important part of education. This arises because character assessment can assess students in learning. Assessment for attitude appears to be a more complex activity in the learning context (Yan, 2018). Database system E-assessment students' self-concept of physics with a "SESKA" system using a Mysql database. MySQL server is a program that stores large amounts of information in an organized format and easily accessible through programming languages like PHP (Yank, 2004). Therefore, with the MySQL database on SESKA, the E-assessment character of students' self-concept of physics makes was easily conducted, even with amount of information inputted by students. The complete research data is presented in the Table 1 .

Table 1. E-assessment of Self-Concept toward Physics

\begin{tabular}{cccccccc}
\hline \multicolumn{2}{c}{ Category } & & Median & Mode & Min's & Max & $\%$ \\
\cline { 1 - 5 } Interval & Attitude & Total & & & & & \\
\hline $44.0-79.2$ & Very bad & 12 & 165 & 156 & 117 & 193 & 2.7 \\
$79.2-114.4$ & Not good & 28 & & & & & 6.3 \\
$114.4-149.6$ & Fair & 60 & & & & & 13.3 \\
$149.6-184.8$ & Good & 212 & & & & & 47.1 \\
$184.8-220$ & Very good & 138 & & & & & 30.6 \\
\multicolumn{2}{l}{ TOTAL } & 450 & & & & $100 \%$ \\
\hline
\end{tabular}

\section{A. Character E-assessment students' self}

E-assessment of students' self-concept character towards physics in this study used a system was developed as "SESKA". This Eassessment was conducted at 450 high school students in Jambi Province, Indonesia. The results of the E-assessment results in students' self-concept of physics (Table 1).

Based on the Table 1, the mode value was 156 , the median value was 165 , the minimum value and maximum were $117 \& 193$, respectfully. While based on the self-concept character category students had different self-character / attitude concepts. They were divided into 5 student characters namely very bad selfattitude attitude character $=2.7 \%$ (12 students), bad character $=6.7 \%$ (28 students), quite good characters $13.3 \%$ (60 students), good characters $=47.1 \%$ (212) and very good characters = $30.6 \%$ (138 students). So, it can be concluded that the character of students' self-concept towards physics in high school students in the Jambi province of Indonesia by using the SESKA E-assessment system shows that good characters have the most dominant value in this study with a percentage $(47.1 \%)$. Thus, this good character can help in improving the quality of learning, especially with teacher responses to the E-assessment concept devoted to physics. 
The teachers at junior high school in Jambi Province of Indonesia responses towards the development of E-assessment with a "SESKA" system are presented in Table 2.

Table 2. Teacher's Response to E-assessment System

\begin{tabular}{cccccccc}
\hline \multicolumn{2}{c}{ Category } & & Mean & Mode & Min & Max & $\%$ \\
\cline { 1 - 3 } Interval & Attitude & Total & & & & & \\
\hline $48-50$ & Very bad & 0 & 4.2 & 4 & 3 & 5 & 0 \\
$50,1-72$ & Bad & 0 & & & & & 0 \\
$72,1-94$ & Fair & 3 & & & & & 20,0 \\
$94,1-116$ & Good & 10 & & & & & 66,7 \\
$116,1-140$ & Very Good & 2 & & & & & 13,3 \\
\multicolumn{2}{c}{ TOTAL } & 15 & & & & \\
\hline
\end{tabular}

Based on the Table 2, the descriptive value for the teacher's response to the E-assessment of self-concept towards Physics shows the mean value of 4 . 2, the mode value of 4 , the minimum value of 3 and maximum of 5 . On the other hand, based on the category of teacher response to the E-Assessment, the character of students' self-concept of physics concludes three different responses. The results of teacher responses concluded from the table show that none of the teacher respondents chose the bad and very bad category. While the other responses for the remaining 3 categories were, fair category got $20 \%$ (3 teachers), good category got $66.7 \%$ (10 teachers), and very good category got $13.3 \%$ (1 teacher). So, it can be concluded that the physics teacher's response to the development of students' self-concept EAssessment of physics in Jambi province, Indonesia showed positive results. This is indicated by the dominant percentage in the good category, with a percentage of $66.7 \%$. Therefore, the needs of students' self-concept assessment of physics must be applied to school students. Thus, the development of the Eassessment of students' self-concept of physics is in line with one of the teacher's tasks as an evaluator.

\section{B. Character Concept Self-E-assessment of "SESKA-based" Physics}

The SESKA system uses program language created on Macromedia Dreamweaver MX 2004 applications in the form of PHP. It uses PHP as a scripting language that embeds HTML from web pages. At SESKA, it uses MySQL as one of the database input servers that aims to store E-assessment information. (Chen \& Hsu, 2014) state that a datacontinuous Structured Query Language (SQL) process is an automated enterprise in formation process that processes continuous incoming data streams. MySQL in the SESKA E-assessment program make the data filled in by respondents directly enter the information database continuously. Thus, it facilitates the assessment process. When the evaluator wants to return to the destination, the webserver executes the PHP script and replaces the results to the page.

Meanwhile, in general, assessment has often been used by education staff to measure the cognitive and learning conditions of students. (Nikou \& Economides, 2018) state that assessment is a critical process in education that features both measuring and supporting student learning. The assessment is not too focused on the assessment of student character. This Eassessment emerged as a more effective and efficient character assessment solution and followed the development of industry 4.0. Eassessment appears to look at the behavior and character of students, primarily the students' self-concept characters in physics. It is important because the behavior is related to students themselves. Self-concept is assumed to be very important and influential factors related to a person's behavior and emotions, as well as cognitive outcomes, such as student academic achievement (Chao et al., 2019).

E-assessment on students' self-concept of physics using a web \& online SESKA system can support the performance of teachers or other stakeholders with more authority in the world of education. The web-based assessments (e-assessment) help the lecturer or teacher to quickly and objectively assess students (Hardianti et al., 2017). The development process of the concept character E-assessment designed for physics can be seen in the Fig. 2. 


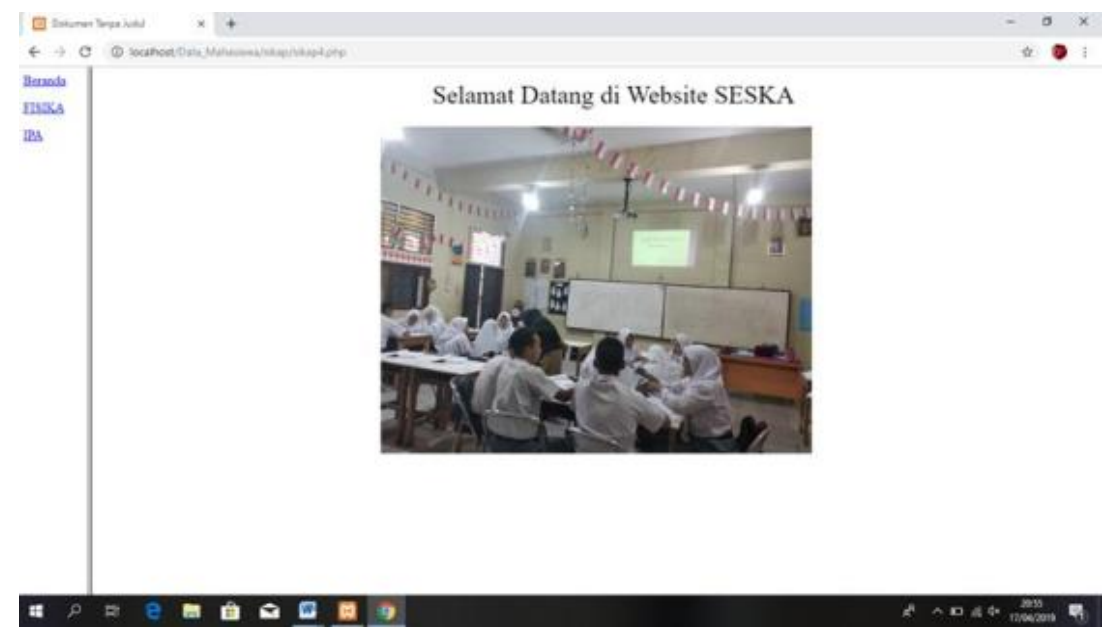

Fig. 2.Home Page E-Assessment discipline toward science on SESKA "

In Fig. 2 a web view of self-concept character E-Assessment is shown. Students took physics subjects with a "SESKA" system. That homepage is shown for every respondent who will use SESKA as a character E-Assessment. On the SESKA home page, the picture above shows 2 class groups who are the respondents of the character's self-assessment E-Assessment of physics. From the results of observations conducted during the implementation of selfconcept research E-Assessment, students provided good and positive responses to $\mathrm{E}$ Assessment. Students felt happy and interested in new ways developed through the SESKA system. This is because there is still very rare internet-based assessment and communication. The students' interest indicates the need for EAssessment to be developed and improved. Because with the use of E-Assessment, researchers or teachers can easily see the current conditions of students related to the concept of the students analyzed efficiently and effectively.

As for the homepage, when the respondent opens SESKA, you see the phrase "Welcome Visitors". That phrase indicates that they have successfully accessed the SESKA System on their communication device (android or computer). In the home page menu, there are several sub-menus that can be accessed by users (Respondents).

\section{E-Assessment: Self-Concept toward Physics}

E-assessment was developed from the questionnaire instrument. The questionnaire inputted with the code developed by the SESKA system aims to create a character selfassessment E-assessment instrument for physics. Fig. $3 \& 4$ shows the form of concept questionnaire E-assessment page written at SESKA.

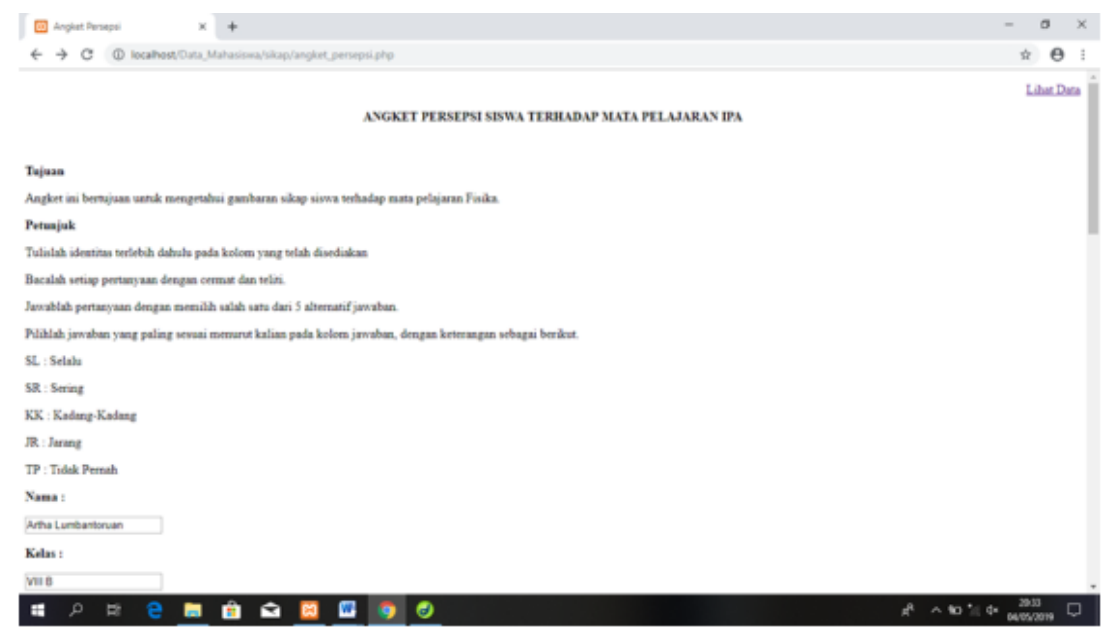

Fig. 3. Self - Concept Toward Physics E-Assessment 


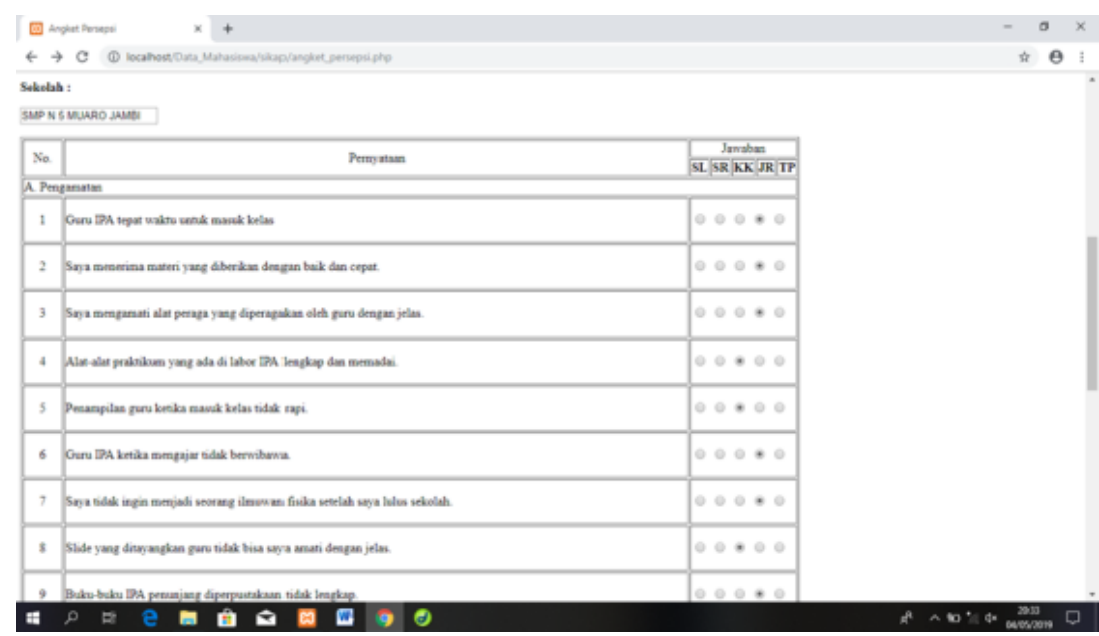

Fig. 4. Assessment Self - Concept toward Physics

Fig. $3 \& 4$ shows the questionnaire display of students' self-concept e-assessment of physics at SESKA. This questionnaire was previously shaped like in general paper-based questionnaire. With the development of EAssessment, the character of the student's selfconcept questionnaire towards physics "Paper" was transformed into E-Assessment with a programming language (coding). That is due to the existing questionnaires still use conventional and manual methods, generally. There are many weaknesses in the paper-based assess- ment. In addition, manual assessment requires direct questionnaire distribution that require a long time. Besides, the process of inputting the data into a computer also requires more time and effort. The manual systems are slow, take a long time, boring, and troublesome for every individual (M. N. Abdullah \& Kadhim, 2016). Therefore, an assessment based on information systems and technology is needed to overcome this problem. This E-assessment appears to facilitate manual assessment by stakeholders of students.

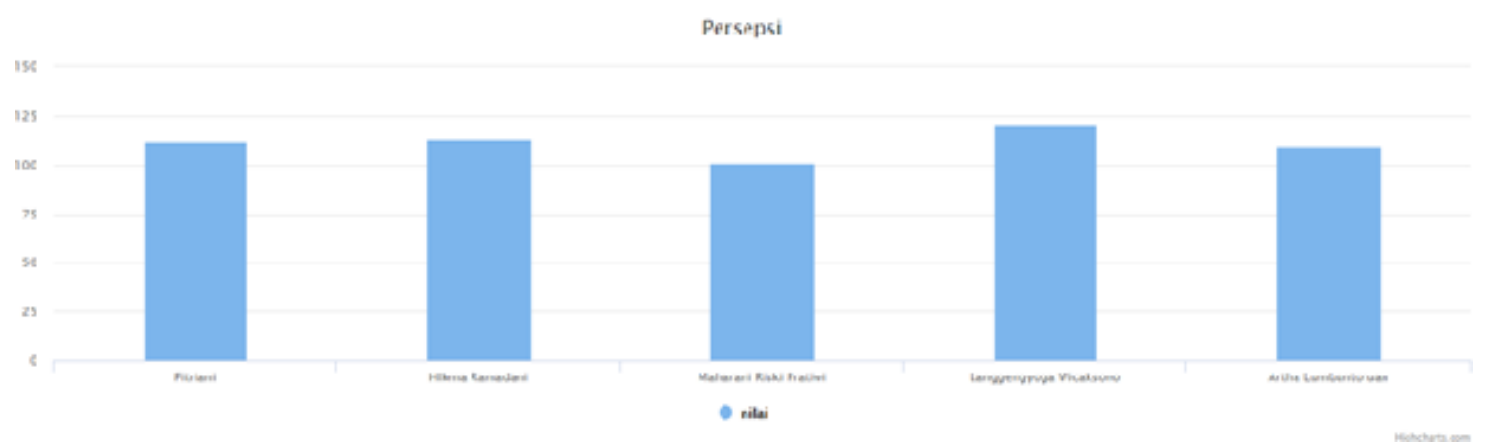

Fig. 5.Graph of Data E-Assessment Results

Fig. 5 shows the results of E-assessment students' self-concept in physics. The bar diagram is an implication of the self-concept of students who have followed the flow of students' self-concept E-assessment. The results of the data were stored in the SESKA database. The database was MySQL. (Welling et al., 2004) state that MySQL is a great tool for learning about databases in general due to the ease of installation and use, as well as the small hard drive and memory footprint. Data put into the concept of self E-Assessment characters were stored in the database. Thus, the respondent using a communication device can connect via the Internet with PHP and MySQL as the server-side responsible for the user's request, processing, and storage or accessing the database (A. Abdullah, 2016). So, it can be concluded that the data we have input entered the SESKA system E-Assessment, displayed as in the picture above.

\section{Conclusion}

Based on the description above, the application of developed SESKA for E-Assessment of students' self-concept towards physics was successful. E-The research on E-assessment of students' self-concept towards physics has been carried out to 450 high school students and 15 
teachers. The results of the description of the SESKA system on self-concept e-assessment of physics for student respondents showed that the dominant character was a good self-concept character with a percentage of $47.1 \%$ (212 students). The responses from teachers who used the E-Assessment physics were analyzed and classified as a good response with a percentage of $66.7 \%$ (10 teachers from 15 teachers). This means that the teacher's response to EAssessment of the student self-concept with the SESKA system is very good. Thus, the eassessment is important to be used because it can ease the assessment process for teachers or students because it is in line with the industrial revolution 4.0.

Based on the results of this study, the application of SESKA system development for EAssessment students' self-concept of physics subjects is recommended. Besides, it is also suggested that material development always be developed in accordance with changes in curriculum or technology. In addition, computer hardware and internet interconnection can be provided optimally so that it does not affect students psychologically in using this system.

\section{References}

Abdullah, A. (2016). Instilling values character education through playing role model in learning history. International Conference on Ethics in Governance (ICONEG 2016).

Abdullah, M. N., \& Kadhim, E. H. (2016). Airline mobile reservation development. Journal in Science, Engineering and Technology, $3(10), \quad 1-3$. https://doi.org/DOI 10.17148/IARJSET.2016.31001

Ardito, C., Costabile, M. F., De Marsico, M., Lanzilotti, R., Levialdi, S., Roselli, T., \& Rossano, V. (2006). An approach to usability evaluation of e-learning applications. Universal Access in the Information Society, 4(3), 270-283. https://doi.org/DOI 10.1007/s10209-0050008-6

Birenbaum, M., Breuer, K., Cascallar, E., Dochy, F., Dori, Y., Ridgway, J., \& Nickmans, G. (2006). A learning integrated assessment system. Educational Research Review, I(1), 61-67.

Chao, C. N. G., McInerney, D. M., \& Bai, B. (2019). Self-efficacy and self-concept as predictors of language learning achievements in an Asian bilingual context. The Asia-Pacific Education Researcher, 28(2), 139-147. https://doi.org/https://doi.org/10.1007/s402 99-018-0420-3

Chen, Q., \& Hsu, M. (2014). Data continuous $S Q L$ process. Google Patents.
Cohen, L., Manion, L., \& Morrison, K. (2013). Research methods in education. Taylor \& Francis Group.

Dwija, I. W. (2008). Hubungan antara konsep diri, motivasi berprestasi dan perhatian orang tua dengan hasil belajar Sosiologi pada siswa kelas II sekolah menengah atas unggulan di kota Amlapura. Jurnal Pendidikan Dan Pengajaran, 41(1).

Fuller, M. B. (2013). An empirical study of cultures of assessment in higher education. Education Leadership Review, 14(1), 2027.

Hardianti, R. D., Taufiq, M., \& Pamelasari, S. D. (2017). The development of alternative assessment instrument in web-based scientific communication skill in science education seminar course. Jurnal Pendidikan IPA Indonesia, 6(1). https://doi.org/DOI:10.15294/jpii.v6i1.788 5

Heitink, M. C., Van der Kleij, F. M., Veldkamp, B. P., Schildkamp, K., \& Kippers, W. B. (2016). A systematic review of prerequisites for implementing assessment for learning in classroom practice. Educational Research Review, 17, 50-62.

Ismail, M. I. (2010). Kinerja dan kompetensi guru dalam pembelajaran. Lentera Pendidikan: Jurnal Ilmu Tarbiyah Dan Keguruan, 13(1), 44-63.

Joshi, A., Kale, S., Chandel, S., \& Pal, D. K. (2015). Likert scale: Explored and explained. British Journal of Applied Science \& Technology, 7(4), 396.

Karyadi, K., Sinon, I. L., Yusuf, I., \& Widyaningsih, S. W. (2018). Correlation analysis between external factors and students' physics learning achievement. Scientiae Educatia: Jurnal Pendidikan Sains, 7(1), 42-54.

Lawrence, A. S., \& Vimala, A. (2013). Selfconcept and achievement motivation of high school students. Online Submission, l(1), 141-146.

Marwan, A., \& Sweeney, T. (2019). Using activity theory to analyse contradictions in english teachers' technology integration. The Asia-Pacific Education Researcher, 28(2), 115-125. https://doi.org/https://doi.org/10.1007/s402 99-018-0418-x

Narmadha, U., \& Chamundeswari, S. (2013). Attitude towards learning of science and academic achievement in science among students at the secondary level. Journal of Sociological Research, 4(2), 114.

Nikou, S. A., \& Economides, A. A. (2018). Mobile-based assessment: A literature review of publications in major referred journals from 2009 to 2018. Computers \& Education, 125, 101-119. 
https://doi.org/https://doi.org/10.1016/j.co mpedu.2018.06.006

Pratiwi, U., \& Fasha, E. F. (2015). Pengembangan instrumen penilaian hots berbasis kurikulum 2013 terhadap sikap disiplin. Jurnal Penelitian Dan Pembelajaran IPA, 1(1), 123-142.

Retnawati, H., Hadi, S., \& Nugraha, A. C. (2017). Implementasi pemanfaatan software penulisan laporan hasil belajar siswa SMK pada pelaksanaan Kurikulum 2013. Jurnal Pendidikan Vokasi, 7(1), 30-42. https://doi.org/http://dx.doi.org/10.21831/j pv.v7i1.12599

Sahidu, H., Gunawan, G., Indriaturrahmi, I., \& Astutik, F. (2017). Desain sistem eassessment pada pembelajaran fisika di LPTK. Jurnal Pendidikan Fisika Dan Teknologi, 3(2), 265-270.

Thapliyal, A., \& Kumar, C. R. S. (2016). Development of data acquisition console and web server using Raspberry Pi for marine platforms. International Journal of Information Technology and Computer Science, 8, 46-53. https://doi.org/DOI: 10.5815/ijitcs.2016.11.06
Topcu, M. S., \& Sahin-Pekmez, E. (2009). Turkish middle school students' difficulties in learning genetics concepts. Journal of Turkish Science Education, 6(2), 55-62.

van Aalderen-Smeets, S. I., Walma van der Molen, J. H., van Hest, E. G. C., \& Poortman, C. (2017). Primary teachers conducting inquiry projects: effects on attitudes towards teaching science and conducting inquiry. International Journal of Science Education, 39(2), 238-256.

Welling, L., Thomson, L., \& Marrara, S. (2004). MySQL tutorial. Pearson Italia Spa.

Yan, Z. (2018). The self-assessment practice scale (SaPS) for students: Development and psychometric studies. The Asia-Pacific Education Researcher, 27(2), 123-135. https://doi.org/https://doi.org/10.1007/s402 99-018-0371-8

Yank, K. (2004). Build your own database driven website using PHP \& MySQL. SitePoint Pty Ltd. 